\title{
Making sense of global integration and local responsiveness in international HRM research
}

Article

Accepted Version

Chung, C. (2018) Making sense of global integration and local responsiveness in international HRM research. International Journal of Multinational Corporation Strategy, 2 (2). 153. ISSN 2059-1047 doi: https://doi.org/10.1504/IJMCS.2018.10010737 Available at https://centaur.reading.ac.uk/72745/

It is advisable to refer to the publisher's version if you intend to cite from the work. See Guidance on citing.

To link to this article DOI: http://dx.doi.org/10.1504/IJMCS.2018.10010737

Publisher: Inderscience

All outputs in CentAUR are protected by Intellectual Property Rights law, including copyright law. Copyright and IPR is retained by the creators or other copyright holders. Terms and conditions for use of this material are defined in the End User Agreement.

www.reading.ac.uk/centaur 
Central Archive at the University of Reading

Reading's research outputs online 


\title{
Making sense of global integration and local responsiveness in international HRM research
}

\author{
Chul Chung* \\ Henley Business School, University of Reading, \\ Whiteknights, Reading, RG6 6UD, UK. \\ Email: c.chung@henley.ac.uk \\ * Corresponding author
}

Chul Chung is an Assistant Professor in International Human Resource Management at Henley Business School, University of Reading, UK. He earned a PhD in Management from Lancaster University Management School. His research focuses on IHRM strategy and practices in multinational corporations, executive staffing, and strategic human resource management. He has published papers in premier journals in International Business and Human Resource Management and coauthored a book and book chapters in Global HRM. 


\title{
Making sense of global integration and local responsiveness
}

\section{in international HRM research}

\begin{abstract}
$\underline{\text { Abstract }}$
While the notions of global integration (GI) and local responsiveness (LR) have been widely used to analyse an MNE's international human resource management (IHRM) strategy, the specific ways of conceptualising these constructs in the literature remain unquestioned. This paper reviews how the two important constructs have been conceptualised in the international HRM research and evaluates whether such conceptualisations are adequate to examine MNEs' IHRM strategies to address the fundamental strategic problem - managing the duality of GI and LR in HRM of MNEs. The extensive review of the literature reveals that the widely used constructs have been rather narrowly conceptualised on a single dimension - HRM practice orientation - in the international HRM literature based on the dualistic assumption on the relationship between the two constructs, which prevents the exploration of emerging broader IHRM strategies. Based on the insights from the emerging literature, it is argued that GI and LR should be conceptualised as meta-level constructs which encompass multiple dimensions so that IHRM strategies could be considered as various configurations of the ways of pursuing GI and LR across the dimensions to address the duality problem in MNEs.
\end{abstract}

Key words: global integration; local responsiveness; international HRM; multinational enterprise 


\section{Introduction}

Multinational enterprises (MNEs) need to achieve integration and control across their globally dispersed units, while responding to unique local requirements in each host country (Park, 2016; Prahalad and Doz, 1987). This duality problem in MNEs - the simultaneous pursuit and achievement of integration and responsiveness in operating across multiple local contexts - has been acknowledged as a fundamental strategic problem that an MNE should deal with (Rosenzweig, 2006; Scott-Kennel and Michailova, 2016). Reflecting this concern, the notions of global integration (GI) and local responsiveness (LR) have been widely used to capture and analyse MNEs' strategies, since Doz, Bartlett and Prahalad (1981) introduced these concepts to studies of MNEs. These constructs have been also applied to the domain of human resource management (HRM) in MNEs to explore international HRM (IHRM) strategies and practices in MNEs.

However, although the two constructs have been the most important concepts in examining and analysing MNEs' IHRM strategies, there has been a lack of in-depth reviews regarding how these two constructs have been conceptualised in the literature. Considering the prevalent use of the constructs in research and practices of HRM in MNEs, this seems to be rather surprising, since a lack of relevant conceptualisation of the key constructs could seriously limit our understanding of IHRM strategies to deal with the fundamental strategic problem in managing MNEs.

This paper addresses the deficiency in the literature by examining the ways of conceptualising GI and LR constructs in the IHRM research to evaluate whether the particular ways of conceptualisation are adequate to examine MNEs' IHRM strategies to address the duality problem in MNEs. The extensive review of the literature makes several contributions to the studies of MNE strategies. First, it points out the limitations of extant conceptualisations of GI and LR in the IHRM literature by revealing that the constructs have 
been conceptualised rather narrowly on a single dimension - practice orientations in terms of global standardisation (GI) or localisation of HRM practices (LR) - based on a dualistic assumption on the relationship between GI and LR. Arguably, the narrow conceptualisation based on the dualistic assumption is problematic as it prevents the exploration of emerging broader IHRM strategies of MNEs, which are potentially more relevant to the issue of managing the duality in MNEs. Emerging empirical studies have also indicated that there might be profoundly different ways and complex patterns in enacting GI and LR in practice. Second, based on the insights from the emerging literature, it offers a novel way of conceptualising GI and LR by suggesting that the two concepts should be conceptualised as meta-level constructs which encompass multiple dimensions so that IHRM strategies could be viewed as various configurations of the ways of pursuing GI and LR across the dimensions, rather than a choice of either global standardisation or localisation of HRM practices across subsidiaries of MNEs. Third, it suggests directions for future research by calling for further in-depth research on how MNEs actually conceptualise and enact the dual demands of GI and LR in their HRM strategy to explicate the underlying construct dimensions of GI and LR.

The following sections review the original conceptions and the operationalisation of GI and LR constructs in the international business strategy literature and then examine how the constructs have been translated and utilised in the research on international HRM strategy and practices of MNEs. Based on the review of the literature, the directions for future research are suggested and, finally, the key contributions of the review are discussed in the concluding section.

\section{The development of GI and LR concepts in the international business research}


The concepts of GI and LR has its roots in the classic work of Lawrence and Lorsch (1969) who pointed out the integration-differentiation issue as a central management concern (Rosenzweig, 2006; Venaik et al., 2004). They argue that in order to achieve its goal effectively, any large organisation needs to pursue differentiation by delegating activities to relevant actors in a manner that enables the actors to focus on a specialised area of activities (Lawrence and Lorsch, 1969). As each differentiated unit may endanger the effectiveness of an entire organisation by pursuing its own goal, it is inevitable that some integration mechanisms are needed to coordinate the differentiated subunits. Thus, how to integrate subunits while allowing them necessary flexibility to respond to their unique contexts is a key challenge for leaders of any large organisations (Cray, 1984; Lawrence and Lorsch, 1969). In order to respond to the challenge, organisations utilise a range of integration mechanisms simultaneously (Martinez and Jarillo, 1989; Lawrence and Lorsch, 1969).

The concepts of GI and LR were developed by Prahalad and Doz (1987) to capture 'environmental pressures' that a business in an MNE faces. They have been used dominantly in the international business research as a framework to explore various international business strategies that MNEs pursue. Even though the terms might refer to broad managerial approaches, the authors used them as a way to identify and classify environmental pressures that lead to the managerial approaches by adding a word 'pressures' to them. They suggested seven factors which are related to the pressures for GI: (1) importance of multinational customers, (2) importance of multinational competitors, (3) investment intensity, (4) technology intensity, (5) pressure for cost reduction, (6) universal needs of customers, and (7) access to raw materials and energy (Prahalad and Doz, 1987). As indicated by these factors, the concept of GI mainly concerns exploiting benefits of scale and scope across various units in an MNE. 
LR refers to the adaptation of an MNE's operations to local conditions. It is mainly driven by situational conditions at the subsidiary level as each subsidiary faces unique needs of local customers, supplier networks, local competitors and government regulations (Prahalad and Doz, 1987). Prahalad and Doz (1987) propose five factors as the pressures for LR: (1) differences in customer needs, (2) differences in distribution channels, (3) availability of substitutes, (4) market structure, and (5) local regulations. Though the GI-LR framework was originally developed to capture environmental pressures in international business context, it has been extended to the different levels such as industry/business, function, and task (Rosenzweig, 2006).

Since the concepts of GI and LR were introduced, researchers in the international business field have utilised the framework in various ways, as summarised in Appendix 1. Here, the specific ways of conceptualising the constructs are reviewed in three respects: (1) concept and dimensions, (2) level of analysis, and (3) relationship between the two constructs.

\subsection{The concept and dimension}

Venaik, Midgley and Devinney (2004) extensively review and analyse how the constructs of GI and LR have been defined and operationalised in the international business literature. They identified two broad categories in the ways of conceptualisation: environmental pressures (e.g. Roth and Morrison, 1990 ; Ghoshal and Nohria, 1993; Johnson, 1995) and managerial responses (e.g. Jarillo and Martinez, 1990; Martinez and Jarillo, 1991; Kobrin, 1991, 1994; Johansson and Yip, 1994; Birkinshaw, Morrison and Hulland, 1995; Murtha, Lenway and Bagozzi, 1998; Taggart, 1998; Harzing, 2000; Luo, 2002). In terms of the environment pressures, Roth and Morrison (1990), for example, suggest fourteen industry variables to operationalize the two pressures in the GI-LR framework. For the pressures for GI, the specific items include: 
- Customer needs are standardised worldwide; standardised purchasing practices exist worldwide; competitors exist with a presence in all key markets; international competition is intense; distribution channels are concentrated worldwide; business activities are susceptible to scale economies; product awareness exists worldwide; standardised product technology exists worldwide; competitors market a standardised product worldwide.

On the other hand, for the pressures for LR, the specific items include:

- Domestic competition is intense; international activities are restrained by governments; transportation cost is an important element in final cost; local customer service is required in all markets; factor costs differ from country to country.

From the list of variables, it is clearly noticeable that the concepts of the pressures for GI and LR encompass various dimensions such as the nature of customers and competition, and the characteristics in operations.

In terms of conceptualising GI and LR as managerial responses, Harzing (2000), for example, defines GI (labelled as interdependence) as the extent to which various units of a MNE are dependent on each other and operationalises the term as three different levels of dependencies measured by the percentage of intra-company sales and purchases:

- Independence (the subsidiary is barely dependent on headquarters or other subsidiaries); dependence (the subsidiary is mainly dependent on headquarters); interdependence (the subsidiary, headquarters and other subsidiaries all form part of an interdependent network).

LR is defined as the extent to which subsidiaries respond to local differences in customer preference and operationalised into four specific items:

- Product modification; adaptation of marketing; local production; local R \& D. 
Another influential example of conceptualising GI and LR as managerial responses can be found in Taggart's work (1998), which operationalises GI, adapting from Prahalad and Doz (1987), as:

- Manufacturing decisions linked to local or worldwide market areas; product specification developed by subsidiary for its own or parent's markets; the extent to which the subsidiary serves MNE customers worldwide market areas; sharing of technology development within the internal network; dependence of subsidiary on linkages within the internal network; centralization of production planning.

LR is measured on a 4-point scale (decided mainly by corporate headquarters without consulting the affiliate; decided mainly by the parent after consulting the affiliate; decided mainly by the affiliate after consulting corporate headquarters; decided mainly by the affiliate without consulting corporate headquarters) in various dimensions such as:

- market area served; product range supplied; advertising and promotion; research and development; production capacity; manufacturing technology.

Again, the concepts of GI and LR as managerial responses include multiple dimensions, though the specific dimensions are varied across the authors.

\subsection{The level of analysis}

Bartlett and Ghoshal (1989) assert that by using the GI-LR framework the relative strength of the pressures for GI or LR could be analysed at the level of industry, business, function or task. The constructs have been utilised at all of these levels in empirical studies. For example, Ghoshal and Nohria (1993) operationalise the forces for GI and LR at the industry level to examine the relationship between MNE environment and MNE structure in their study of 41 North American and European MNEs. Kobrin (1991) also uses the concept of GI to identify determinants of global integration at the industry level by analysing 56 manufacturing industries. 
The concepts have also been used at the business unit level (e.g. Roth and Morrison, 1990; Kobrin, 1994; Johnson, 1995; Kim, Park and Prescott, 2003). For instance, Birkinshaw, Morrison and Hulland (1995) examine the structural and competitive determinants of a global integration strategy and their effects on performance by studying 124 businesses of US MNEs. They define business unit integration as the "rationalization that may entail standardisation of product, centralization of technological development, or the vertical or horizontal integration of manufacturing" by adopting Kobrin's definition (Kobrin, 1991, p. 19) and use measurements which are related to various integration mechanisms: for example, international control of manufacturing; control within the organisation of the international transfer of intangible assets; vertically integrate operations worldwide; horizontally integrate operations worldwide.

Although not specified by Bartlett and Ghoshal (1989), there have been studies which extended the use of the concepts to the subsidiary level (e.g. Jarillo and Martinez, 1990; Martinez and Jarillo, 1991; Taggart, 1998; Harzing, 2000; Luo, 2002; Venaik, Midgley and Devinney, 2004). Jarillo and Martinez (1990) adapt the GI and LR constructs to develop and test a framework that characterises different subsidiary roles with 50 Spanish subsidiaries of MNEs. In their study, the integration of activities is defined as the level of integration of a subsidiary with its parent organisation and the localisation of activities is conceptualised as the degree of localisation in the strategy of a subsidiary in terms of local production, local content in locally produced goods, the amount of local R \& D, and the local adaptation of products.

Finally, the constructs of GI and LR have been used at the function level. One of the rare function-level studies was conducted by Kim, Park and Prescott (2003), examining the pattern of utilising different integrating modes by MNEs to achieve the global integration of their individual business functions and the impact on the performance of the firm. In their 
research, GI refers to the degree of realizing control and coordination in a business function of an MNE across borders. Control refers to aligning subsidiaries' activities with corporate centre's expectations, whereas coordination refers to establishing linkages between geographically dispersed units (Kim et al., 2003). Based on the conceptions, they operationalise the concept of GI in two ways: the outcome and the modes of integration. In terms of the outcome, they use the term, "integration effectiveness", and define it as "the degree of effectiveness in general of the use of integrating modes in globally coordinating and controlling the chosen function" (Kim et al., 2003, p. 335). Regarding the modes of integration, they distinguish four integration modes such as people-based, formalisationbased, centralisation-based, and information-based integrating mode and identify that each function uses a different combination of the integrating modes to achieve the integration effectiveness. One of the key contributions of this study is the adoption of the configurational view in conceptualising GI across the multiple dimensions. I will pick up this insight and elaborate further in a later section where I discuss the direction of future research.

\subsection{The relationship between $G I$ and $L R$}

When the GI-LR framework was initially introduced to the international strategy research, the simultaneous attainment of GI and LR - 'transnational solution'- was contended as a highly desirable strategy (Bartlett and Ghoshal, 1989). Roth and Morrison (1990) assert that the GI-LR framework has two important strengths: first, it is parsimonious yet account for significant variation across organisations; second, it allows international strategy to be conceptualised through alternate contextual settings, rather than a single dimensional context. Most studies assumed that the two constructs are independent constructs rather than opposite ends of a single continuum. For example, Johnson (1995) verifies the utility of the GI-LR framework in analysing international strategies and shows that three generic strategies suggested by the framework appear even in a single industry context: globally integrated, 
locally responsive and multifocal. Similarly, Jarillo and Martinez (1990) identify three roles of subsidiary, which are receptive, active, and autonomous subsidiaries, based on the dimensions of integration and localisation.

Through the review of the literature, we can summarize the ways of conceptualising the constructs in the international business research as follows:

- There is a lack of consensus on the ways of conceptualising GI and LR constructs among the researchers. However, the constructs tend to be conceptualised across multiple dimensions.

- The concepts have been used across different levels such as industry, business, subsidiary, and function.

- GI and LR have been conceptualised as independent constructs which can be pursued simultaneously.

These points indicate that the notions of GI and LR could be viewed as meta-level concepts encompassing multiple dimensions, which are not self-apparent concepts, but ones that need further specifications.

\section{The application of GI and LR concepts in the international HRM research}

As far as the international HRM research is concerned, it is widely agreed that managing tensions between GI and LR is a key issue in HRM of MNEs (Rosenzweig 2006; Edwards and Kuruvilla, 2005; Evans, Pucik and Barsoux 2002). A significant amount of research on the issue has examined the degree of GI and LR in IHRM strategies and practices (e.g. Björkman and Lervik, 2007; Farndale and Paauwe, 2007; Farndale, Brewster and Poutsma, 2008; Brewster, Wood and Brookes, 2008). This section reviews how the GI and LR constructs have been picked up and applied within the international HRM research, as summarised in Appendix 2. In so doing, I draw attention to some of the limitations that this 
'translation' of the constructs across fields has resulted in. As with my previous summary of the treatment of GI and LR in the international business literature, I summarise the use of GILR concepts in the IHRM field in three aspects: the dimension, the level of analysis, and the relationship between the two constructs. I also begin to problematize the way in which the original thinking in the international business literature about GI and LR has been adapted and applied within the IHRM field.

\subsection{The concept and dimension}

In the studies on managing GI and LR in HRM of MNEs, the terms have been used to describe and analyse international HRM strategies and practices. A significant amount of research on the HRM of MNEs has examined the degree of GI and LR by assessing whether a particular HRM practice resembles parent firm's practices or local practices (Chung, Sparrow and Bozkurt, 2014). It tends to be assumed that the similarity between subsidiary HRM practices and parent practices indicates GI; whereas the resemblance between subsidiary HRM practices with local practices is considered as a proxy of LR. For example, in their early research on the international HRM strategy of MNE subsidiaries in Taiwan, Hannon, Huang and Jaw (1995, p. 542) operationalised GI as the degree of "importing HR strategies from headquarters" and LR as the degree of "customizing HR strategies to respond to the needs of the local environment" and used several related survey items to measure the subsidiary's current state of GI and LR across six HRM practice areas such as promotion and career system, compensation and reward systems, staffing activities and so on. They identified three types of international HRM strategy such as autonomous, receptive and active strategy by using a two-by-two matrix of GI and LR, each measured by the practices orientations, and showed that GI is related to subsidiary's dependence on parent's resources, while LR is associated with the dependence on local resources. 
In another pioneering study of HRM of 249 U.S. subsidiaries of MNEs, Rosenzweig and Nohria (1994) examine whether subsidiary HRM practices resemble parent practices or local ones and identified contextual factors that influence the pattern of practice resemblance. It was identified that the degree of LR is high when a subsidiary is founded by acquisition and more dependent upon local input, while the high frequency of communication and presence of expatriates in a subsidiary have negative influence on the degree of LR. Tayeb (1998) also conducted research on the degree of standardisation and localisation by examining the extent of transferring parent HRM policies to a subsidiary such as recruitment, development, compensation and benefit, industrial relation, teamwork, flexible working, and quality control through a case study of a Scottish subsidiary of a US MNE. The study showed that some practices were successfully transferred, but other practices were significantly modified or rejected by the subsidiary.

Another type of empirical research is based on measuring indirectly the extent of standardisation or localisation by testing statistically the degree of similarity in HRM practices among selected groups of organisations such as MNE subsidiaries from different home countries and indigenous firms in a same host country context (e.g. Turner, D'Art and Gunnigle, 1997; Ngo, Turban, Lau and Lui, 1998; Tregaskis, Heraty and Morley, 2001; Schmitt and Sadowski, 2003; Kim and Gray, 2005). For example, Turner et al. (1997) examined the extent of country of origin effect on subsidiary HRM practices by conducting a survey with 101 subsidiaries of MNEs and local firms in Ireland and compare HRM practices such as performance-related pay, human resource flow practices and employee involvement between the indigenous and the foreign companies in Ireland. Ngo et al. (1998) explored country of origin effects on HRM practices of MNE subsidiaries through a survey with 253 local firms, and US, UK, and Japanese MNEs in Hong Kong. They classified 25 HRM practices into 4 groups such as structured training, retention-oriented compensation, 
seniority-based compensation, and diversity practices and compared among four groups (US, UK, Japanese MNEs and local firms) across the four areas of practices.

As shown in these exemplar studies, earlier empirical studies on the issue of managing GI and LR in HRM of MNEs tend to conceptualise the constructs of GI and LR rather narrowly by operationalising them on the single dimension of practice orientation. The degree of standardisation (versus localisation) of subsidiary HRM practices has been considered as a key dimension underlying different orientations in IHRM strategy (Brewster et al., 2008; Pudelko and Harzing, 2007; Dickmann and Müller-Camen, 2006). For example, one of the influential models of IHRM developed by Taylor, Beechler and Napier (1996) identifies three generic IHRM orientations at the MNE corporate-level: exportive, adaptive, and integrative orientations. In this model, the issue of managing the demands of GI and LR is translated into the matter of global standardisation and localisation of HRM practices.

The particular conceptualisation of the constructs in the IHRM research is contrasting to the original development in the international business strategy research, as GI and LR have been viewed in the IB research as much broader concepts, encompassing diverse dimensions across the different levels. Pudelko and Harzing (2007) observe that the issue of standardisation versus localisation has been more concerned in functional area such as marketing and HRM. However, the standardisation of practices is only one of the integration mechanisms even at the function-level (Kim et al., 2003). It is questionable whether the conceptualisation of GI and LR based on practice orientations is comprehensive enough to reflect potentially various ways of achieving GI and LR in practice.

\subsection{The level of analysis}

While there are different levels of analysis in HRM studies such as strategy, practice, or task, when the degrees of GI and LR have been examined in the international HRM research, the main focus has been on the HRM practice level (e.g. performance management, recruitment 
and selection, compensation etc.) or the overall aggregated level through the use of integrative measures of subsidiary HRM practices (Björkman, 2006), while few studies have been conducted at the overall IHRM strategy level.

In terms of organisational level, most empirical studies which examine the GI-LR issue in HRM of MNEs have been conducted at the subsidiary level, though conceptual models of IHRM strategy at the MNE corporate-level exist (e.g. Taylor et al., 1996). For example, a study on HRM practices of MNEs by Björkman and his colleagues (2007) examined the determinants of HRM practices, such as employee training, performance-based compensation, competence/performance appraisal, merit-based promotion and internal communication, in subsidiaries of MNEs and tested the impact of a host country and subsidiary characteristics on the degree of using each HRM practice. Bae et al. (1998) examined the determinants of subsidiary HRM practices in MNEs by surveying $190 \mathrm{MNE}$ subsidiaries and indigenous firms operating in Taiwan and South Korea. They measured the tendencies of each HRM practice in terms of whether a firm relies on high performance HRM policies or more traditional ones and examined the influences of host countries and home countries on subsidiary HRM practices.

\subsection{The relationship between GI and LR}

While the original conception of GI and LR treated the two constructs as qualitatively different concepts, they were viewed implicitly as poles in a single scale of continuum in international HRM research. This is related to the aforementioned single dimensionality in conceptualising the two constructs. Conceptualising GI and LR on the single dimension of practice orientation would lead to a dualistic view which considers the issue of managing GI and LR as either-or-choice between global standardisation and localisation of practices (Evans et al., 2002). 
It should be noted that though the studies on GI and LR have examined whether subsidiary HRM practices are similar to parent or local practices, the results of the studies have shown the pattern of hybridisation of global and local practices in many cases (e.g. Hannon et al., 1995; Liberman and Torbiorn, 2000; Schmitt and Sadowski, 2003; Tayeb, 1998; Brewster et al., 2008). For instance, Brewster et al. (2008) examined the influences on subsidiary HRM practices with a survey of 6939 MNE subsidiaries and domestic firms in 20 countries and investigated the degree of similarity in HRM practices amongst different groups (domestic firm versus foreign MNEs, domestic MNEs versus foreign MNEs) and their findings showed the mixed influences of global and local factors.

\footnotetext{
"Table 1 goes about here"
}

Through the extensive review of the extant literature in the international business as well as the international HRM literature (Table 1), it becomes clear that the constructs of GI and LR need to be revisited and developed further. The review of the international business literature reveals that the key limitations in conceptualising the GI and LR constructs are the lack of consensus on the definition of the concepts and the problem of under-specification in domain and dimension, which call for further conceptual clarification (Venaik et al., 2004). On the other hand, in the international HRM research, there has been no in-depth discussion with regard to how the constructs of GI and LR should be conceptualised in the context of HRM in MNEs, though the constructs have been conceptualised rather narrowly in terms of the dimension and the level of analysis and the relationship between the two constructs. 
Arguably, this narrow conceptualisation might limit our investigation of emerging IHRM strategies in practice to deal with the GI-LR duality problem in MNEs.

\section{The directions for future research: re-articulating GI and LR in IHRM}

The review of the literature enables us to identify particular ways of conceptualising GI and LR in the international HRM research. To gain managerial relevance in conceptualising the key constructs, we need to clarify research problems by identifying the taken-for-granted assumptions, which have never been reviewed critically, as summarised in Table 2 . This section discusses why the current ways of conceptualising GI and LR would be problematic in addressing the strategic problem in HRM of MNEs. Then, directions for future research are presented to advance the research on IHRM strategy of MNEs across the three respects we considered in the review of the literature.

"Table 2 goes about here"

\subsection{GI and LR as meta-constructs with multiple dimensions}

From the review of the international HRM literature, it is evident that examining GI and LR on the single dimension of practice orientation has been a major concern in previous studies. The current conceptualisation of the constructs seems to be largely taken-for-grated, based on the assumption that GI and LR can be achieved through global standardisation and localisation of practices, respectively. This narrow conceptualisation with the dualistic mindset may unnecessarily constrain our view and thus limit our exploration of other possible ways to address the problem of achieving GI and LR in HRM of MNEs.

Emerging studies indicate that GI and LR are actually much broader constructs which encompass multiple dimensions than conventionally thought of (e.g. Dickmann and Müller- 
Camen, 2009; Smale, 2008; Evans et al., 2002). There are a range of mechanisms that MNEs utilise to integrate their geographically dispersed operations and adapt them to specific local contexts. For example, Smale (2008) found several key modes of global HRM integration by examining 20 Finnish subsidiaries in China, following Kim and his colleagues' typology (2003) on integration modes such as people-based, formalization-based, information-based, and centralization-based mechanisms. Considering the diversity of integration and adaptation mechanisms, it would be reasonable to view GI and LR as meta-constructs with multiple dimensions which reflect these mechanisms.

However, the specific dimensions underlying GI and LR in HRM of MNEs are largely under-examined empirically. An exception to this was the study conducted by Sparrow, Brewster and Harris $(2004 ; 2005)$. They identified five organisational drivers which lead to different patterns of international HRM strategy, namely: efficiency orientation, global service provision, information exchange, core business processes and localisation of decisionmaking. However, this study is more concerned with the organisational drivers which are related to general patterns in globalising HRM, rather than specifically focusing on the ways pursuing GI and LR in HRM of MNEs. Arguably, the dimensions underlying GI and LR can be identified through inductive empirical investigations of the ways of pursuing GI and LR that are utilised in practice. A confirmatory mode of study with pre-defined categories might prohibit a researcher from identifying the ways that are actually conceived and enacted in practice by managers. Thus, future research would benefit from an explorative and inductive study without a confined view.

\subsection{Exploring MNE-level IHRM strategy}

As evidenced by the review of IHRM literature, most studies examining the GI-LR issue in HRM of MNEs have been conducted at the level of subsidiary HRM practices. It seems to be largely assumed that decisions on GI and LR would be made at this micro-level, focusing on 
whether an HRM practice is standardised across subsidiaries or localized in a particular local context. Studies at the subsidiary level would be important, as a subsidiary's HR function is placed in a critical position to implement corporate HRM strategies, facing both the pressures for GI from HQ and those for LR from distinct local conditions.

However, the studies at the subsidiary-level may not be sufficient to fully understand how an MNE conceptualise and implement the notions of GI and LR in its overall HRM function. What has been missing is a study of IHRM strategy at the MNE corporate level. If we accept the multi-dimensionality of the two constructs, the issue of managing GI and LR in HRM of MNEs needs to be examined at a broader level such as MNE corporate level. Even though there was a call for examining the issue at an MNE's entire function level (e.g. Malnight, 1995), actual empirical works at the MNE corporate level have been lacking. As Smale's study (2008) has indicated, a study on the issue of managing GI and LR at an MNE's IHRM strategy level could reveal various dimensions underlying the two constructs. In addition, a multi-level study of how the GI and LR constructs are interpreted and enacted by various groups of actors promises to be highly important, as apparently similar notions can be interpreted differently by different actors (Budhwar and Sparrow 2002).

\subsection{The relationship between GI-LR: Duality}

The original conception of the two constructs in the international business strategy literature implied the potential 'duality' of the two constructs. However, it was argued that the constructs have been conceptualised largely in a dualistic ways in the international HRM research, as attention has been given to the practice orientation towards either standardisation or localisation.

However, as the duality view suggested (Evans, 1999), the dualistic conceptualisation of the two constructs might mislead researchers only to be constrained in a dilemma situation. According to the duality perspective, responding to the dual pressures should not be regarded 
as an 'either-or' choice, but a duality which should be reconciled (Evans 1999). In the literature, the duality view has been discussed in two ways: hybridization in practices and multi-dimensional configuration.

First, at the HRM practice level, actual empirical findings have revealed much more complex patterns of hybridization between global standardisation and localisation than what has been viewed in the literature. Several studies show that an IHRM strategy and practice could be far more nuanced and complex than what a simplistic framework would suggest. For example, several studies suggested that a number of complex patterns of transfer, negotiation and combination of practices emerge in the process of globalising HRM (Edwards and Rees, 2008; Edwards and Tempel, 2010; Edwards, 2011; Edwards, Jalette and Tregaskis, 2012). In a case study of Japanese multinational retail firms in both their home country and their subsidiaries in China, Gamble (2010) argues that previous theoretical approaches to the transfer of HRM practices in MNEs could provide only a partial explanation on the nature of managing the dual requirements of GI and LR. In order to capture the complexity of IHRM, he proposed the concept of 'hybridization', the complex patterns of creating new management practices out of highly selective adoption and adaptation. Through the extensive review of literature on the issue, Edwards and Kuruvilla (2005, p. 8) concludes that: "Arguably, most empirical studies acknowledge that both global and local factors are in evidence... The theme of the 'hybridization' of global and local influences is sometimes picked up explicitly, with it being argued that HR practice in MNCs is a balance of the two." Even when parent practices are imposed to subsidiaries, they still have to be 'negotiated' with local norms (Morgan, 2005; Geppert, Williams and Matten, 2003).

Second, at the broader MNE-strategy-level, the duality of GI and LR could be managed through a multi-dimensional configuration. For example, even when processes are standardised to integrate a function (GI), local responsiveness can be pursued simultaneously 
by staffing local people in key positions of a subsidiary. Similarly, Johansson and Yip (1994, p. 580) also claimed that: “...global strategy is multidimensional. Setting strategy for a worldwide business requires choices along a number of strategic dimensions. Some of these dimensions determine whether the strategy lies towards the multi-local end of the continuum or the global end.” Dickmann and Müller-Camen (2006) also conceptualised IHRM strategy as various configurations across standardisation and knowledge-network dimensions. By adopting the configurational view, we might be able to overcome the dualistic thinking and conceive the seemingly contradictory concepts as duality. While there are a number of studies which examined the patterns of hybridisation at the level of HRM practices, few studies have highlighted the pattern of multi-dimensional configuration to manage the dual demands of GI and LR in HRM of MNEs. Thus, the pattern of configuring HRM activities across multiple dimensions to achieve GI and LR simultaneously in MNEs deserves further investigations.

\section{Conclusion}

For the last two decades, IB and IHRM scholars have widely used the concepts of GI and LR in their studies of MNE strategies and HRM practices. This paper is one of few attempts to review how the two constructs have been conceptualised in the international HRM research. Through the extensive review of the literature, this paper makes several contributions to the studies of MNEs. First, the critical review reveals the key limitations in the ways of conceptualising GI and LR in the international HRM literature, namely, the single dimensionality, the limited focus on subsidiary HRM practices and the dualistic assumption on the relationship between the two constructs. This particular conceptualisation of the constructs makes us view the issue of achieving GI and LR as a matter of choosing either global standardisation or localisation of HRM practices, rather than a duality to pursue both. 
Second, based on the awareness of the limitations in conceptualising GI and LR in the extant literature, it suggests an alternative way of conceptualising GI and LR in the international HRM research, emphasising the multi-dimensionality of the constructs, the extended focus on MNE-level IHRM strategy, and the duality of the two constructs. Hence, IHRM strategies could be viewed as various configurations of the ways of pursuing GI and LR across the multiple dimensions.

Finally, this review suggests a direction for future research by calling for explorative studies which examine how MNEs actually conceptualise and enact the dual demands of GI and LR in their HRM strategies to explicate the underlying construct dimensions of GI and LR. The identification of the dimensions would contribute to the development of a new IHRM strategy framework, which can be utilised to examine various configuration and hybridisation patterns across the dimensions. It will enable IHRM researchers to capture and analyse MNEs' emerging IHRM strategies to achieve both GI and LR more comprehensively, and thus contributes to our understanding of MNE strategy at a function level. 


\section{References}

Bae, J., Chen, S. and Lawler, J. (1998) 'Variations in HRM in Asian countries: MNC home country and host country effects', International Journal of Human Resource Management, Vol. 9, No. 4, pp. 653-70.

Bartlett, C. and Ghoshal, S. (1989) Managing across borders: The transnational solution, Harvard Business School Press, Boston.

Birkinshaw, J. M., Morrison, A. J. and Hulland, J. (1995) 'Structural and competitive determinants of a global integration strategy', Strategic Management Journal, Vol. 16, pp. 637-655.

Björkman, I. (2006) 'International human resource management research and institutional theory', in Stahl, G. and Björkman, I. (Eds.), Handbook of Research in International Human Resource Management, Edward Elgar, Cheltenham, pp.463-473.

Björkman, I. and Lervik, J.E. (2007) 'Transferring HR practices within multinational corporations', Human Resource Management Journal, Vol. 17, pp. 320-335.

Brewster, C., Sparrow, P.R. and Harris, H. (2005) 'Towards a new model of globalising HRM', International Journal of Human Resource Management, Vol. 16, No. 6, pp. 949-970.

Brewster, C., Wood, G. and Brookes, M. (2008) 'Similarity, isomorphism or duality? Recent survey evidence on the human resource management policies of multinational corporations', British Journal of Management, Vol. 19, pp. 320-342.

Budhwar, P.S. and Sparrow, P. (2002) 'Strategic HRM through the cultural looking glass: mapping the cognition of British and Indian managers', Organisation Studies, Vol. 23, pp. 599-638. 
Chung, C., Sparrow, P., and Bozkurt, Ö. (2014) ‘South Korean MNEs’ international HRM approach: Hybridization of global standards and local practices', Journal of World Business, Vol. 49, pp. 549-559.

Cray, D. (1984) 'Control and coordination in multinational corporations', Journal of International Business Studies, Vol. 15, pp. 85-98.

Dickmann, M. and Müller-Camen, M. (2006) 'A typology of international human resource management strategies and processes', International Journal of Human Resource Management, Vol. 17, No. 4, pp. 580-601.

Doz, Y., Bartlett, C. and Prahalad, C. (1981) 'Global competitive pressures and host country demands: managing tensions in MNCs', California Management Review, Spring, pp. 63-74.

Edwards, T. (2011) 'The nature of international integration and HR policies in multinational companies', Cambridge Journal of Economics, Vol. 35, No. 3, pp. 483-498.

Edwards, T., Jalette, P. and Tregaskis, O. (2012) 'To what extent is there a regional logic in the management of labour in multinational companies? Evidence from Europe and North America', International Journal of Human Resource Management, Vol. 23, No. 12, pp. 2468-2490.

Edwards, T., and Kuruvilla, S. (2005) 'International HRM: national business systems, organisational politics and the international division of labour in MNCs', International Journal of Human Resource Management, Vol. 16, No. 1, pp. 1-21.

Edwards, T., and Rees, C. (2008) International Human Resource Management: Globalisation, National Systems and Multinational Companies, Financial Times/ Prentice Hall, London. 
Edwards, T. and Tempel, A. (2010) 'Explaining variation in the reverse diffusion of HR practices: evidence from the German and British subsidiaries of American multinationals', Journal of World Business, Vol. 45, No. 1, pp. 19-28.

Evans, P. (1999) 'HRM on the edge: A duality perspective', Organisation, Vol. 6, pp. 325338.

Evans, P., Pucik, V., and Barsoux, J.-L. (2002) The Global Challenge: Frameworks for International Human Resource Management, McGraw Hill-Irwin, New York.

Farndale, E., Brewster, C. J. and Poutsma, E. (2008) 'Co-ordinated vs. liberal market HRM: the impact of institutionalisation on multinational firms', International Journal of Human Resource Management, Vol. 19, pp. 2004-2023.

Farndale, E. and Paauwe, J. (2007) 'Uncovering competitive and institutional drivers of HRM practices in multi-national corporations', Human Resource Management Journal, Vol. 17, No. 4, pp. 355-375.

Gamble, J. (2010) 'Transferring organisational practices and the dynamics of hybridization: Japanese retail multinationals in China', Journal of Management Studies, Vol. 47, pp. 705-732.

Geppert, M. , Williams, K. and Matten, D. (2003) 'The Social Construction of Contextual Rationalities in MNCs: An Anglo-German Comparison of Subsidiary Choice', Journal of Management Studies, Vol. 40, No. 3, pp. 617-640.

Ghoshal, S. and Nohria, N. (1993) 'Horses for courses: Organisational forms for multinational corporations', Sloan Management Review, Vol. 34, No. 2, pp. 23-35.

Hannon, J. M., Huang, I.-C., and Jaw, B.-S. (1995) 'International human resource strategy and its determinants: The case of subsidiaries in Taiwan', Journal of International Business Studies, Vol. 26, pp. 531-554. 
Harzing, A-W. (2000) 'An empirical analysis and extension of the Bartlett and Ghoshal typology of multinational companies', Journal of International Business Studies, Vol. 31, No. 1, pp. 101-132.

Jarillo, J. C., and Martinez, J. I. (1990) 'Different roles for subsidiaries: The case of multinational corporations in Spain', Strategic Management Journal, Vol. 11, No. 7, pp. 501-512.

Johansson, J. K. and Yip, G. S. (1994) 'Exploiting globalization potential: U.S. and Japanese strategies', Strategic Management Journal, Vol. 15, pp. 579-601.

Johnson, J. Jr. (1995) 'An empirical analysis of the integration-responsiveness framework:

U.S. construction equipment industry firms in global competition', Journal of International Business Studies, Vol. 26, No. 3, pp. 621-35.

Kim, Y. and Gray, S. (2005) 'Strategic factors influencing international human resource management practices: an empirical study of Australian multinational corporations', International Journal of Human Resource Management, Vol. 16, No. 5, pp. 809-830.

Kim, K., Park, J. H., and Prescott, J. E. (2003) 'The global integration of business functions: A study of multinational businesses in integrated global industries', Journal of International Business Studies, Vol. 34, No. 4, pp. 327-344.

Kobrin, S. J. (1991) 'An empirical analysis of the determinants of global integration', Strategic Management Journal, Summer Special Issue, Vol. 12, pp. 17-31.

Kobrin, S. J. (1994) 'Is there a relationship between a geocentric mind-set and multinational strategy?', Journal of International Business Studies, Vol. 25, No. 3, pp. 493-511.

Lawrence, P., and Lorsch, J. (1967) Organisation and environment: Managing differentiation and integration, Division of Research, Graduate School of Business Administration, Harvard University, Boston. 
Liberman, L. and Torbiorn, I. (2000) 'Variances in staff-related management practices at eight European country subsidiaries of a global firm', International Journal of Human Resource Management, Vol. 11, No. 1, pp. 37-59.

Luo, Y. (2002) 'Organisational dynamics and global integration: a perspective from subsidiary managers', Journal of International Management, Vol. 8, pp. 189-215.

Malnight, T. (1995) 'Globalization of an ethnocentric firm: An evolutionary perspective', Strategic Management Journal, Vol. 16, pp. 119-141.

Martinez, J. and Jarillo, J. (1989) 'The evolution of research on coordination mechanisms in multinational corporations', Journal of International Business Studies, Vol. 20, pp. 489-511.

Martinez, J. and Jarillo, J. (1991) 'Coordination demands of international strategies', Journal of International Business Studies, Vol. 22, No. 3, pp. 429-444.

Morgan, G. (2005) 'Understanding multinational corporations', in Oxford Handbook of Work and Organisation, eds. Ackroyd, S., Batt, R., Thompson, P. and Tolbert, P., Oxford University Press, Oxford, pp. 554-576.

Murtha, T., Lenway, S., and Bagozzi, R. (1998) 'Global mindsets and cognitive shifts in a complex multinational corporation', Strategic Management Journal, Vol. 19, No. 2, pp. $97-114$.

Ngo, H., Turban, D., Lau, C., and Lui, S. (1998) 'Human resource practices and firm performance of multinational corporations: influences of country origin', International Journal of Human Resource Management, Vol. 9, No. 4, pp. 632-652.

Park, B.I. (2016) 'The future journey of International Journal of Multinational Corporation Strategy', International Journal of Multinational Corporation Strategy, Vol. 1, No. 1, pp.1-17. 
Prahalad, C. and Doz, Y. (1987) The multinational mission: Balancing local demands and global vision, New York: Free Press.

Pudelko, M., and Harzing, A.-W. (2007) 'Country-of-origin, localisation, or dominance effect? An empirical investigation of HRM practices in foreign subsidiaries', Human Resource Management, Vol. 46, pp. 535-559.

Rosenzweig, P.M. (2006) 'The dual logics behind international human resource management: pressures for global integration and local responsiveness', in Stahl, G.K. and Björkman, I. (Eds.), Handbook of Research in International Human Resource Management, Edward Elgar, Cheltenham, pp. 36-48.

Rosenzweig, P. M. and Nohria, N. (1994) 'Influences on human resource management practices in multinational corporations', Journal of International Business Studies, Vol. 25, No. 2, pp. 229-251.

Roth, K. and Morrison, A. (1990) 'An empirical analysis of the integration-responsiveness framework in global industries', Journal of International Business Studies, Vol. 22, No. 4, pp. 541-61.

Schmitt, M. and Sadowski, D. (2003) 'A cost-minimization approach to the international transfer of HRM/IR practices: Anglo-Saxon multinationals in the Federal Republic of Germany', International Journal of Human Resource Management, Vol. 14, No. 3, pp. 409-30.

Scott-Kennel, J. and Michailova, S. (2016) 'Subsidiary internal and external embeddedness: trade-up and trade-off', International Journal of Multinational Corporation Strategy, Vol. 1, No. 2, pp.133-154.

Smale, A. (2008) 'Foreign Subsidiary Perspectives on the Mechanisms of Global HRM Integration', Human Resource Management Journal, Vol. 18, pp. 135-153. 
Sparrow, P.R., Brewster, C. and Harris, H. (2004) Globalising Human Resource Management, London: Routledge.

Taggart, J.H. (1998) 'Strategy shifts in MNC subsidiaries', Strategic Management Journal, Vol. 19, No. 7, pp. 663-681.

Tayeb, M. (1998) 'Transfer of HRM practices across cultures: an American company in Scotland', International Journal of Human Resource Management, Vol. 9, No. 2, pp. $332-358$.

Taylor, S., Beechler, S., and Napier, N. (1996) 'Toward an integrative model of strategic international human resource management', Academy of Management Review, Vol. 21, pp. 959-985.

Tregaskis, O., Heraty, N. and Morley, M. (2001) 'HRD in multinationals: the global/local mix', Human Resource Management Journal, Vol. 11, No. 2, pp. 34-56.

Turner, T., D’Art, D. and Gunnigle, P. (1997) 'Pluralism in retreat? A comparison of Irish and multinational manufacturing companies', International Journal of Human Resource Management, Vol. 8, No. 6, pp. 825-40.

Venaik, S., Midgley, D., and Devinney, T. (2004) 'A new perspective on the integrationresponsiveness pressures confronting multinational firms', Management International Review, Vol. 44, No. 1, pp. 15-48. 
Table 1 The summary of review on conceptualisations of GI-LR in the literature

\begin{tabular}{|c|c|c|}
\hline Area of concern & $\begin{array}{c}\text { International business } \\
\text { literature } \\
\text { (Original conceptions and } \\
\text { applications) } \\
\end{array}$ & $\begin{array}{l}\text { International HRM literature } \\
\text { (Applications to IHRM) }\end{array}$ \\
\hline \multirow[t]{2}{*}{$\begin{array}{l}\text { Concept/ } \\
\text { dimension }\end{array}$} & $\begin{array}{l}\text { - Various concepts in terms of } \\
\text { domain (environmental } \\
\text { pressures, managerial } \\
\text { response) }\end{array}$ & $\begin{array}{l}\text { - Focus on a particular mode: } \\
\text { standardisation versus } \\
\text { localisation in HRM practices }\end{array}$ \\
\hline & $\begin{array}{l}\text { - Multi-dimensional: diverse } \\
\text { aspects of environment, } \\
\text { industry, business, and } \\
\text { function }\end{array}$ & - Single dimensional \\
\hline \multirow[t]{4}{*}{ Level of analysis } & • Industry & - Subsidiary and practice \\
\hline & - Firm/business & \\
\hline & - Function & \\
\hline & - Subsidiary & \\
\hline $\begin{array}{l}\text { Relationship } \\
\text { between GI and } \\
\text { LR }\end{array}$ & $\begin{array}{l}\text { - Duality: attention to the dual } \\
\text { accomplishment of } \\
\text { integration and } \\
\text { responsiveness }\end{array}$ & $\begin{array}{l}\text { - Dualistic: attention to the } \\
\text { practice orientation towards } \\
\text { either standardisation or } \\
\text { localisation }\end{array}$ \\
\hline $\begin{array}{l}\text { Issues in } \\
\text { conceptualisation }\end{array}$ & $\begin{array}{l}\text { - Lack of consensus } \\
\text { - Under-specification }\end{array}$ & $\begin{array}{l}\text { - Absence of review of } \\
\text { constructs } \\
\text { - Narrow operationalisation }\end{array}$ \\
\hline
\end{tabular}


Table 2 The specification of research requirements

\begin{tabular}{|c|c|c|c|}
\hline $\begin{array}{l}\text { Area of } \\
\text { concern }\end{array}$ & International HRM literature & Implicit assumption/gap & Research problem \\
\hline $\begin{array}{l}\text { Concept/ } \\
\text { dimension }\end{array}$ & $\begin{array}{l}\text { - Focus on standardisation versus } \\
\text { localisation in HRM practices } \\
\text { - Single dimensional }\end{array}$ & $\begin{array}{l}\text { - GI/LR mainly occurs at the practice } \\
\text { dimension }\end{array}$ & - Possibility of multi-dimensionality \\
\hline $\begin{array}{l}\text { Level of } \\
\text { analysis }\end{array}$ & - Subsidiary and practice & $\begin{array}{l}\text { - GI/LR mainly occurs at the subsidiary } \\
\text { practice level }\end{array}$ & $\begin{array}{l}\text { - Lack of examining MNE-level IHRM } \\
\text { strategy }\end{array}$ \\
\hline $\begin{array}{l}\text { Relationship } \\
\text { between GI } \\
\text { and LR }\end{array}$ & $\begin{array}{l}\text { - Dualistic: attention to the practice } \\
\text { orientation towards either } \\
\text { standardisation or localisation }\end{array}$ & - GI-LR is a matter of 'either-or-choice' & - Possibility of duality \\
\hline
\end{tabular}




\section{Appendix 1 The summary of conceptualisations of GI and LR in the international business research}

\begin{tabular}{|c|c|c|c|}
\hline $\begin{array}{l}\text { Authors } \\
\text { (year) }\end{array}$ & $\begin{array}{l}\text { Domain / Level of } \\
\text { analysis }\end{array}$ & Construct label & Definition/Operationalization/dimension \\
\hline $\begin{array}{l}\text { Roth \& } \\
\text { Morrison } \\
(1990)\end{array}$ & $\begin{array}{l}- \text { Environmental pressure } \\
\cdot \text { Business unit }\end{array}$ & NA & $\begin{array}{l}\bullet \text { No definition } \\
\text { - Fourteen industry variables were used to classify groups based on the two pressures of the Prahalad-Doz framework. (e.g. } \\
\text { customer needs are standardized worldwide; standardized purchasing practices exist worldwide; competitors exist with a } \\
\text { presence in all key markets; international competition is intense; distribution channels are concentrated worldwide etc.) }\end{array}$ \\
\hline \multirow[t]{2}{*}{$\begin{array}{l}\text { Jarillo \& } \\
\text { Martinez } \\
(1990)\end{array}$} & \multirow[t]{2}{*}{$\begin{array}{l}\text { - Managerial response } \\
\text { - Subsidiary }\end{array}$} & $\begin{array}{l}\text { Integration of } \\
\text { activities }\end{array}$ & $\begin{array}{l}\text { - The level of integration of the subsidiary with the parent organisation } \\
\text { - Result of factor analysis of } 9 \text { strategy variables: percentage of purchases coming from the group (parent company and other } \\
\text { subsidiaries); level of integration in purchasing; percentage of products sold in the local market that are produced (at least } \\
\text { partially) by the subsidiary; percentage of local content in products made locally; level of integration in manufacturing; } \\
\text { proportion of the R\&D performed in the subsidiary; level of integration in R\&D; percentage of products specially created or } \\
\text { substantially adapted to the domestic market of the subsidiary; level of integration in marketing }\end{array}$ \\
\hline & & $\begin{array}{l}\text { Localization of } \\
\text { activities }\end{array}$ & $\begin{array}{l}- \text { The amount of localization in the strategy of subsidiary } \\
\text { - Local production; local content in locally produced goods; amount of local R\&D; adaptation of products }\end{array}$ \\
\hline \multirow{2}{*}{$\begin{array}{l}\text { Martinez \& } \\
\text { Jarillo } \\
(1991)\end{array}$} & \multirow[t]{2}{*}{$\begin{array}{l}\text { - Managerial response } \\
\text { - Subsidiary }\end{array}$} & $\begin{array}{l}\text { Integration of } \\
\text { activities }\end{array}$ & $\begin{array}{l}\text { - The level of integration of the subsidiary with the parent organisation } \\
\text { - Result of factor analysis of } 9 \text { strategy variables (Same with the research in 1990) }\end{array}$ \\
\hline & & $\begin{array}{l}\text { Localization of } \\
\text { activities }\end{array}$ & $\begin{array}{l}- \text { The amount of localization in the strategy of subsidiary } \\
\text { - Local production; local content in locally produced goods; amount of local R\&D; adaptation of products }\end{array}$ \\
\hline $\begin{array}{l}\text { Kobrin } \\
(1991)\end{array}$ & $\begin{array}{l}\bullet \text { Managerial response } \\
\cdot \text { Industry } \\
\cdot \text { LR not covered }\end{array}$ & $\begin{array}{l}\text { Transnational } \\
\text { integration }\end{array}$ & $\begin{array}{l}\bullet \text { Rationalization that may entail standardization of product, centralization of technological development, or the vertical or } \\
\text { horizontal integration of manufacturing } \\
\text { - Intra-firm flow of resources: intra-firm trade (the sum of affiliate-to-affiliate, affiliate-to-parent, parent-to-affiliate sales) as a } \\
\text { portion of all international sales (the sum of parent export sales and all affiliates' sales) }\end{array}$ \\
\hline \multirow{2}{*}{$\begin{array}{l}\text { Ghoshal \& } \\
\text { Nohria } \\
(1993)\end{array}$} & \multirow[t]{2}{*}{$\begin{array}{l}- \text { Environmental pressure } \\
\text { - Industry \& company }\end{array}$} & $\begin{array}{l}\text { Forces for global } \\
\text { integration }\end{array}$ & $\begin{array}{l}\bullet \text { Pressures to subsidiaries to coordinate their activities due to linkages across national boundaries } \\
\bullet \text { Kobrin's index of integration: same above (Kobrin, 1991)- aggregated at the industry level (all MNEs in an industry) }\end{array}$ \\
\hline & & $\begin{array}{l}\text { Forces for national } \\
\text { responsiveness }\end{array}$ & $\begin{array}{l}\text { - Local contingencies presented by the multiple environments (local customers, governments, regulatory agencies etc.) in } \\
\text { which a subsidiary operates } \\
\text { - above/below the mean of either variable: the advertising-to-sales ratio of an industry, average of the values on the } \\
\text { questionnaire for the extent of local regulation by industry }\end{array}$ \\
\hline $\begin{array}{l}\text { Kobrin } \\
(1994)\end{array}$ & $\begin{array}{l}- \text { Managerial response } \\
\cdot \text { Company } \\
\cdot \text { LR not covered }\end{array}$ & Global strategy & $\begin{array}{l}- \text { Relatively transnationally integrated industry (each industry classified based on literature) } \\
\text { - No operationalization }\end{array}$ \\
\hline
\end{tabular}




\begin{tabular}{|c|c|c|c|}
\hline $\begin{array}{l}\text { Authors } \\
\text { (year) }\end{array}$ & $\begin{array}{c}\text { Domain / Level of } \\
\text { analysis }\end{array}$ & Construct label & Definition/Operationalization/dimension \\
\hline $\begin{array}{l}\text { Johansson \& } \\
\text { Yip (1994) }\end{array}$ & $\begin{array}{l}- \text { Managerial response } \\
\cdot \text { Business unit } \\
\text { - LR not covered }\end{array}$ & Global strategy & $\begin{array}{l}\text { - Seeks to maximize worldwide performance through sharing and integration across subsidiaries } \\
\text { - } 5 \text { dimensions (Yip, 1989; 1992) included: global share balance; standardized products; activity concentration (average of } \\
\text { measures in R\&D, purchasing, raw material processing, sub-assembly, final assembly, marketing, selling, distribution and } \\
\text { service); marketing uniformity; integrated competitive moves }\end{array}$ \\
\hline $\begin{array}{l}\text { Birkinshaw, } \\
\text { Morrison \& } \\
\text { Hulland } \\
(1995)\end{array}$ & $\begin{array}{l}- \text { Managerial response } \\
\text { (global integration } \\
\text { strategy) } \\
\text { - Business unit } \\
\text { - LR not covered }\end{array}$ & $\begin{array}{l}\text { Business Unit } \\
\text { Integration }\end{array}$ & $\begin{array}{l}- \text { Rationalization that may entail standardization of product, centralization of technological development, or the vertical or } \\
\text { horizontal integration of manufacturing (Korbin, 1991: 19) } \\
\text { - } 8 \text { items (6 used in the analysis) covering various integration area/methods (the importance of methods potentially used to } \\
\text { compete internationally): international control of manufacturing; control within the organization of the international transfer } \\
\text { of intangible assets; vertically integrate operations worldwide; horizontally integrate operations worldwide etc. }\end{array}$ \\
\hline $\begin{array}{l}\text { Johnson } \\
\text { (1995) }\end{array}$ & $\begin{array}{l}\cdot \text { Environmental pressure } \\
\cdot \text { Business unit }\end{array}$ & NA & $\begin{array}{l}\bullet \text { No definition } \\
\text { - Cluster analysis was used to define and classify strategic groups (three groups) based on executive perceptions on sixteen } \\
\text { industry variables (e.g. standardized customer needs worldwide; standardized purchasing; competitors exist in key markets; } \\
\text { domestic competition is intense etc.) }\end{array}$ \\
\hline \multirow[t]{3}{*}{$\begin{array}{l}\text { Murtha, } \\
\text { Lenway \& } \\
\text { Bagozzi } \\
(1998)\end{array}$} & \multirow[t]{3}{*}{$\begin{array}{l}- \text { Managerial response } \\
\text { - Individual manager } \\
\text { (attitude or cognitive } \\
\text { orientation) }\end{array}$} & $\begin{array}{l}\text { Integration } \\
\text { expectations }\end{array}$ & $\begin{array}{l}\text { - Integration refers to the centralized management of geographically dispersed or non-dispersed activities on an ongoing basis } \\
\text { in response to pressures to reduce costs and optimize investment. } \\
\text { - 'As the company globalizes, the country operations most familiar to me will: } \\
\text { - have global marketing responsibility for one or more products. } \\
\text { - produce one or more products for global markets. } \\
\text { - go global with locally developed products. } \\
\text { - lead global product development processes.' }\end{array}$ \\
\hline & & $\begin{array}{l}\text { Responsiveness } \\
\text { expectations }\end{array}$ & $\begin{array}{l}\text { - Local responsiveness refers to resource commitment decisions taken autonomously by a subsidiary in response to primarily } \\
\text { local competitive, political, or customer demands. } \\
\text { - 'As the company globalizes, I believe that the country operations most familiar to me will: } \\
\text { - demonstrate clear benefits to the local economy. } \\
\text { - have flexibility to respond to local conditions. } \\
\text { - harmonize the company's activities and products with national government policies. } \\
\text { - adapt existing products to local markets.' }\end{array}$ \\
\hline & & $\begin{array}{l}\text { Country } \\
\text { coordination } \\
\text { expectations }\end{array}$ & $\begin{array}{l}\text { - The management of flows, commonalities, and scope economies in a multinational network of affiliates } \\
\text { - 'As the company globalizes, I believe that the country operations most familiar to me will: } \\
\text { - provide early warning of global competitive threats. } \\
\text { - put global objectives ahead of country bottom line. } \\
\text { - identify local business opportunities with global potential. } \\
\text { - learn from the company's operations in other countries.' }\end{array}$ \\
\hline
\end{tabular}




\begin{tabular}{|c|c|c|c|}
\hline $\begin{array}{c}\text { Authors } \\
\text { (year) }\end{array}$ & $\begin{array}{l}\text { Domain / Level of } \\
\text { analysis }\end{array}$ & Construct label & Definition/Operationalization/dimension \\
\hline \multirow[t]{2}{*}{$\begin{array}{l}\text { Taggart } \\
(1998)\end{array}$} & \multirow[t]{2}{*}{ - Managerial response } & Integration & $\begin{array}{l}\text { - No definition } \\
\text { [Adapted from Prahalad and Doz (1987)]: } \\
\text { manufacturing decisions linked to local or worldwide market areas; product specification developed by subsidiary for its own } \\
\text { or parent's markets; the extent to which the subsidiary serves MNC customers worldwide market areas; sharing of } \\
\text { technology development within the internal network; dependence of subsidiary on linkages within the internal network; } \\
\text { centralization of production planning }\end{array}$ \\
\hline & & Responsiveness & $\begin{array}{l}\text { - No definition } \\
\text { market area served (Hedlund, 1981); product range supplied (Egelhoff, 1988); advertising and promotion (Takeuchi and } \\
\text { Porter, 1986); research and development (De Meyer, 1993); production capacity (Gates and Eglehoff, 1986); manufacturing } \\
\text { technology (Young et al., 1988). } \\
\text { measured on a 4-point scale as follows: } \\
\text { 1 = decided mainly by HQ without consulting the affiliate; } 2 \text { = decided mainly by the parent after consulting the affiliate; } 3= \\
\text { decided mainly by the affiliate after consulting HQ; } 4=\text { decided mainly by the affiliate without consulting HQ. }\end{array}$ \\
\hline \multirow[t]{2}{*}{$\begin{array}{l}\text { Harzing } \\
(2000)\end{array}$} & \multirow[t]{2}{*}{$\begin{array}{l}- \text { Managerial response } \\
\text { - Subsidiary }\end{array}$} & Interdependence & $\begin{array}{l}\text { - The extent to which various units of a MNE are dependent on each other and so the level of integration within the MNE as a } \\
\text { whole } \\
\text { - Three different levels of dependencies (measured by the percentage of intra-company sales and purchases): independence } \\
\text { (the subsidiary is barely dependent on headquarters or other subsidiaries); dependence (the subsidiary is mainly dependent on } \\
\text { headquarters); interdependence (the subsidiary, headquarters and other subsidiaries all form part of an interdependent } \\
\text { network) }\end{array}$ \\
\hline & & $\begin{array}{l}\text { Local } \\
\text { responsiveness }\end{array}$ & $\begin{array}{l}\text { - the extent to which subsidiaries respond to local differences in customer preferences } \\
\text { - product modification; adaptation of marketing; local production; local R\&D (measured by the percentage of products and } \\
\text { marketing that was substantially modified for the local markets; the percentage of local R\&D and local production } \\
\text { incorporated in products sold by the subsidiary) }\end{array}$ \\
\hline Luo (2002) & $\begin{array}{l}- \text { Managerial response } \\
- \text { Subsidiary }\end{array}$ & $\begin{array}{l}\text { Overall } \\
\text { integration }\end{array}$ & $\begin{array}{l}\text { - The degree of how well integrated a subsidiary is with the rest of the MNE network in terms of internalization, coordination } \\
\text { and interdependence. } \\
\text { - 'Overall, to what extent do you think your head office seeks financial and operational synergies from global integration of } \\
\text { your activities in China with the rest of the network?; Overall, to what extent do you think intra-firm coordination and } \\
\text { integration between your operations in China and the rest of the network is always maintained even though the dynamics of } \\
\text { the Chinese market necessitate the adoption of different strategies and policies under different institutional and market } \\
\text { conditions?; Overall, to what extent do you think your interdependence with the rest of the network, with regard to resources, } \\
\text { knowledge and transactions, is high?' }\end{array}$ \\
\hline \multirow{2}{*}{$\begin{array}{l}\text { Kim, Park \& } \\
\text { Prescott } \\
(2003)\end{array}$} & \multirow{2}{*}{$\begin{array}{l}- \text { Organisational } \\
\text { outcomes/ Managerial } \\
\text { response } \\
\text { - Business }\end{array}$} & $\begin{array}{l}\text { Integration } \\
\text { effectiveness }\end{array}$ & $\begin{array}{l}\text { - The degree of effectiveness in general of the use of integrating modes in globally coordinating and controlling the chosen } \\
\text { function }\end{array}$ \\
\hline & & Integrating modes & $\begin{array}{l}\text { - People-based integrating mode: international transfers of people; liaison personnel to integrate activities internationally etc.; } \\
\text { Formalization-based integrating mode: fairly well-specified worldwide common rules and policies; fairly well-specified } \\
\text { worldwide standard operating procedures etc; Centralization-based integrating mode: the extent of local vs headquarters' } \\
\text { influence on various decision areas; R\&D: R\&D program, project selection etc.; Information-based integrating mode: } \\
\text { databases to share information internationally; world-wide electronic communications systems etc. }\end{array}$ \\
\hline
\end{tabular}




\begin{tabular}{|c|c|c|c|}
\hline $\begin{array}{c}\text { Authors } \\
\text { (year) }\end{array}$ & $\begin{array}{c}\text { Domain / Level of } \\
\text { analysis }\end{array}$ & Construct label & Definition/Operationalization/dimension \\
\hline \multirow[t]{4}{*}{$\begin{array}{l}\text { Venaik, } \\
\text { Midgley \& } \\
\text { Devinney } \\
(2004)\end{array}$} & \multirow{4}{*}{$\begin{array}{l}\text { - Distinguish } \\
\text { environmental pressure } \\
\text { from managerial } \\
\text { response } \\
\text { - Subsidiary (a business } \\
\text { unit in a subsidiary) }\end{array}$} & $\begin{array}{l}\text { Environmental } \\
\text { pressures for } \\
\text { global integration }\end{array}$ & $\begin{array}{l}\text { - 'the impact of global competition' and 'pressures from technological change' (from the interpretation of the factor analysis } \\
\text { result) } \\
\text { - e.g. Competitors are mostly global; competitors sell globally standardised products; the nature of competition is global etc. } \\
\text { (from } 48 \text { measurement items from previous literature) }\end{array}$ \\
\hline & & $\begin{array}{l}\text { Environmental } \\
\text { pressures for local } \\
\text { responsiveness }\end{array}$ & $\begin{array}{l}\text { - 'pressures from the local business infrastructure' } \\
\text { • e.g. Quality of local infrastructure: logistics; channels; advertising; personnel; suppliers }\end{array}$ \\
\hline & & $\begin{array}{l}\text { Global integration } \\
\text { as firm responses }\end{array}$ & $\begin{array}{l}\text { - 'intra-firm sharing of resources' } \\
\bullet \text { e.g. Sharing of production resources; R\&D resources; management services }\end{array}$ \\
\hline & & $\begin{array}{l}\text { Local } \\
\text { responsiveness as } \\
\text { firm responses }\end{array}$ & $\begin{array}{l}\text { • ‘the influence of local regulations on firm decisions' } \\
\text { • e.g. Product decisions; price decisions; advertising decisions; promotion decisions; sourcing decisions; R\&D decisions } \\
\text { influenced by government }\end{array}$ \\
\hline
\end{tabular}




\section{Appendix 2 The summary of conceptualisations of GI and LR in the international HRM research}

\begin{tabular}{|c|c|c|c|}
\hline Authors (year) & $\begin{array}{l}\text { Dimension/ Level of } \\
\text { analysis }\end{array}$ & Construct name & Definition/Operationalization \\
\hline \multirow[t]{2}{*}{$\begin{array}{l}\text { Rosenzweig } \\
\text { \& Nohria } \\
(1994)\end{array}$} & \multirow{2}{*}{$\begin{array}{l}\text { - Subsidiary HRM } \\
\text { practice (benefits, time } \\
\text { off, executive bonus, } \\
\text { participation, gender } \\
\text { composition, training }\end{array}$} & $\begin{array}{l}\text { Difference from } \\
\text { parent (internal } \\
\text { consistency) }\end{array}$ & $\begin{array}{l}- \text { Degree of difference in a subsidiary HRM practice from parent's } \\
\text { - Indicator of internal consistency: compare subsidiary practice with parent practice and transform the data into the degree of } \\
\text { difference }\end{array}$ \\
\hline & & $\begin{array}{l}\text { Difference from } \\
\text { local (local } \\
\text { isomorphism) }\end{array}$ & $\begin{array}{l}\text { - Degree of difference in a subsidiary HRM practice from local's } \\
\text { - Indicator of local isomorphism: compare subsidiary practice with local practice and transform the data into the degree of } \\
\text { difference }\end{array}$ \\
\hline \multirow[t]{2}{*}{$\begin{array}{l}\text { Hannon et al. } \\
(1995)\end{array}$} & \multirow[t]{2}{*}{$\begin{array}{l}\text { - Subsidiary HRM } \\
\text { practices }\end{array}$} & Global integration & $\begin{array}{l}\text { - Subsidiary's current state of global integration } \\
\text { - Degree of importing HR strategies from headquarters: aggregate measures of } 6 \text { HRM practices }\end{array}$ \\
\hline & & $\begin{array}{l}\text { Local } \\
\text { responsiveness }\end{array}$ & $\begin{array}{l}\text { - Subsidiary's current state of local responsiveness } \\
\text { - Degree of customizing HR strategies to respond to the needs of the local environment: aggregate measures of } 6 \text { HRM } \\
\text { practices }\end{array}$ \\
\hline $\begin{array}{l}\text { Turner et al. } \\
(1997)\end{array}$ & $\begin{array}{l}- \text { Subsidiary HRM } \\
\text { practices }\end{array}$ & NA & $\begin{array}{l}\text { - Compare HRM practices between indigenous and foreign companies in Ireland (the use of performance-related pay; } \\
\text { human resource flow practices; employee involvement at the task level) }\end{array}$ \\
\hline $\begin{array}{l}\text { Ding et al. } \\
(1997)\end{array}$ & $\begin{array}{l}- \text { Subsidiary HRM } \\
\text { practices }\end{array}$ & NA & $\begin{array}{l}\text { - Descriptive analysis on each HRM practices of subsidiaries of MNEs (recruitment; training; compensation; performance } \\
\text { appraisal etc.) }\end{array}$ \\
\hline $\begin{array}{l}\text { Ngo et al. } \\
\text { (1998) }\end{array}$ & $\begin{array}{l}- \text { Subsidiary HRM } \\
\text { practices ( } 25 \text { practices } \\
\text { classified into } 4 \text { factors) }\end{array}$ & NA & $\begin{array}{l}-25 \text { human resource management practices items (Peck, 1994) } \\
\text { - Factor analysis to identify dimensions: } 4 \text { factors identified (Structured training; retention-oriented compensation; seniority- } \\
\text { based compensation; diversity) } \\
\text { - Compare the degree of each practice factor amongst four groups (US, UK, Japanese MNEs and local firms) }\end{array}$ \\
\hline Tayeb (1998) & $\begin{array}{l}- \text { Subsidiary HRM } \\
\text { practices }\end{array}$ & NA & $\begin{array}{l}\text { - Examine the extent of transfer of parent policies to subsidiary HRM policies and practices (recruitment; development; } \\
\text { compensation \& benefit; industrial relation; teamwork; flexible working; quality control) }\end{array}$ \\
\hline $\begin{array}{l}\text { Bae et al. } \\
(1998)\end{array}$ & $\begin{array}{l}\bullet \text { Subsidiary HRM } \\
\text { practices (12 practices) }\end{array}$ & NA & $\begin{array}{l}\text { - Measure tendencies of each HRM practices and test the impact of host countries and home countries on each of } 12 \mathrm{HRM} \\
\text { practices }\end{array}$ \\
\hline $\begin{array}{l}\text { Liberman \& } \\
\text { Torbiorn } \\
(2000)\end{array}$ & $\begin{array}{l}- \text { Subsidiary management } \\
\text { practices }\end{array}$ & NA & $\begin{array}{l}\text { - Examine variances and commonalities within/between subsidiaries in HRM practices (communication \& influence; } \\
\text { control; reinforcement; decisions; crisis \& conflict management; instruction \& progression). }\end{array}$ \\
\hline $\begin{array}{l}\text { Tregaskis et } \\
\text { al.(2001) }\end{array}$ & $\begin{array}{l}\text { - Subsidiary HRM } \\
\text { practices (specific HRD } \\
\text { practices: e.g. career } \\
\text { development, skill } \\
\text { development etc.) }\end{array}$ & NA & $\begin{array}{l}\text { - Test the degree of similarity in the HRD practices (5 practices) among different groups (MNE vs. indigenous, UK vs. } \\
\text { Ireland) }\end{array}$ \\
\hline
\end{tabular}




\begin{tabular}{|c|c|c|c|}
\hline Authors (year) & $\begin{array}{c}\text { Dimension/ Level of } \\
\text { analysis }\end{array}$ & Construct name & Definition/Operationalization \\
\hline $\begin{array}{l}\text { Gamble } \\
(2003)\end{array}$ & $\begin{array}{l}- \text { Subsidiary HRM } \\
\text { practices }\end{array}$ & NA & $\begin{array}{l}\text { - Examine similarities between subsidiary and HQ practices vs. similarities between subsidiary and local practices (state- } \\
\text { owned enterprises) across } 8 \text { HRM areas (communication; hierarchy; reward system; benefit; work pattern; age } \\
\text { composition; training; employee representation). }\end{array}$ \\
\hline $\begin{array}{l}\text { Schmitt \& } \\
\text { Sadowski } \\
\text { (2003) }\end{array}$ & $\begin{array}{l}\text { - Subsidiary HRM } \\
\text { practices (HRM/IR } \\
\text { practices) }\end{array}$ & NA & $\begin{array}{l}\text { - Test the degree of similarity(differences) in the HRM/IR practices among different groups (UK/US MNEs vs. German } \\
\text { local firms) }\end{array}$ \\
\hline $\begin{array}{l}\text { Kim \& Gray } \\
(2005)\end{array}$ & $\begin{array}{l}\text { - Subsidiary HRM } \\
\text { practices }\end{array}$ & $\begin{array}{l}\text { Degree of } \\
\text { similarity of } \\
\text { practices (to } \\
\text { parent's) }\end{array}$ & $\begin{array}{l}\text { - The extent to which the HRM system of subsidiary is similar to that of parent } \\
\text { - Degree of similarity to parent practice: aggregate measures of } 11 \text { sub-component of HRM practices }\end{array}$ \\
\hline $\begin{array}{l}\text { Björkman et } \\
\text { al. (2007) }\end{array}$ & $\begin{array}{l}\text { - Subsidiary HRM } \\
\text { practices }\end{array}$ & NA & $\begin{array}{l}\text { - Measure the degree of using HRM practices (employee training; performance-based compensation; } \\
\text { competence/performance appraisal; merit-based promotion; internal communication) and test the impact of host country } \\
\text { and subsidiary characteristics on the use of each HRM practice }\end{array}$ \\
\hline $\begin{array}{l}\text { Brewster et al. } \\
(2008)\end{array}$ & $\begin{array}{l}\text { - Subsidiary HRM } \\
\text { practice (Employer- } \\
\text { employee } \\
\text { interdependence, } \\
\text { delegation to employee) }\end{array}$ & $\begin{array}{l}\text { NA (Degree of } \\
\text { similarity of } \\
\text { practices) }\end{array}$ & $\begin{array}{l}\text { - Test the degree of similarity in the HRM practices ( } 2 \text { defining features and } 6 \text { sub-dimension in HRM practices) amongst } \\
\text { different groups }\end{array}$ \\
\hline
\end{tabular}

